\title{
Development of molecular oncohematology in Ukraine
}

\author{
G. D. Telegeev, M. V. Dybkov, A. N. Dubrovska, D. A. Miroshnichenko,
} A. P. Tyutyunnykova, S. S. Maliuta

Institute of Molecular Biology and Genetics, NAS of Ukraine 150, Akademika Zabolotnogo Str., Ukraine, 03680

g.d.telegeev@imbg.org.ua

\begin{abstract}
Disruption of the genetic component of cells are mandatory element of malignant transformation. For the majority of blood neoplasias genetic disorders have been discovered, and they can be used for diagnosis and appropriate therapy. The data obtained by authors about the role of domains of Bcr-Abl protein (the main etiological factor in the pathogenesis of leukemia with Ph-chromosome) are presented in this review as well as approved diagnostic methods for myeloproliferative disorders and acute leukemias.
\end{abstract}

Keywords: myeloproliferative neoplasms, Bcr-Abl, Jak2, molecular pathogenesis, diagnostics.

Introduction. Malignant tumors are the second (after cardiovascular diseases) cause of deaths in developed countries. According to the Bulletin of National Cancer Registry of Ukraine [1], blood system neoplasms were $4.87 \%$ of total cancer cases in 2011. Proportion of deaths from leukemias is $5.38 \%$ of all cancer deaths cases. Each year about 7,500-8,000 cases of different blood neoplasms are recorded. Myeloproliferative diseases (neoplasms) (MPN) are a biologically heterogenous group of hematopoietic system diseases, the main feature of which is uncontrolled proliferation of stem hematopoietic cells or myelopoiesis progenitor cells $[2,3]$. The MPN part in total blood neoplasms is about 30-35\%. According to the $\mathrm{WHO}$ classification, there are cronic myeloid leukemia (CML), chronic neutrofilic leukemia, chronic eosinophilic leukemia, polycythemia vera, essential polycythemia, primary myelofibrosis, and unclassified myeloproliferative neoplasms [4, 5].

Sharing common morpho-clinical and hematologic features, these diseases, however, have different molecular basis. One of the most represented diseases in this group is CML. CML has a distinctive marker - Philadelphia $\left(\mathrm{Ph}^{\prime}\right)$ chromosome, which is a result of recipro-

(c) Institute of Molecular Biology and Genetics, NAS of Ukraine, 2013 cal translocation $\mathrm{t}(9 ; 22)$ (q34; q11). This chromosome is present in CML and in some patients with acute lymphoblastic leukemia (ALL). A fusion of two genes occurs at the molecular level: $a b l$ on chromosome 9 and $b c r$ on chromosome 22 . The breaks in $a b l$ occur mostly between $1^{\text {st }}$ and $2^{\text {nd }}$ exones and rarely between $2^{\text {nd }}$ and $3^{\text {rd }}$. In contrast, $b c r$ gene has three areas where the breaks happen frequently. Therefore, depending on the breakpoint in $b c r$ gene there are three different forms of BcrAbl protein: $\mathrm{p} 190, \mathrm{p} 210, \mathrm{p} 230$. Each form was found in the certain type of leukemia: p210 Bcr-Abl - in 90-95\% of CML cases, p190 Bcr-Abl - mainly in ALL in adults ( $35 \%$ of all ALL cases), while p230 is found in relatively benign neutrophilic form of myeloid leukemia.

The impetus for the studying of molecular and genetic aspects of these diseases, which has been started at our institute in the 1990s, was a pure practical problem - the development of a system for detecting chimeric fusion of $b c r-a b l$ gene in the patients who were diagnosed and treated in the hematology departments of Kyiv hospitals. The cytogenetic methods used to confirm the presence of the Philadelphia chromosome required the bone marrow puncture, a long time for analysis, highly qualified staff, etc. Using the reverse transcriptase polymerase chain reaction with specific primers allowed 
us to obtain the results within one day after taking patients' peripheral blood samples [6-8]. For the first time in Ukraine the guidelines «The monitoring of chronic myeloid leukemia with molecular methods» [9] have been created and approved by the Ministry of Health. This allowed us to introduce molecular genetic approaches to clinical practice.

However, as it often happens, the practice highlighted a wide range of unsolved scientific problems. Of particular interest was the fact that different forms of Bcr-Abl protein (especially p190 and p210) are specific for leukemias, which differ by the nature of clinical manifestations. The difference between these proteins is that protein Bcr incorporates DH (Dbl-homologous) and $\mathrm{PH}$ (pleckstrin-homologous) domains in the area distinguishing the forms of chimeric proteins p190 and p210 Bcr-Abl. The experimental data could not describe the functional activity of these domains as a part of $\mathrm{Bcr}$, and in $\mathrm{p} 210 \mathrm{Bcr}-\mathrm{Abl}$. PH domain has not been studied at all. It was therefore decided to investigate the areas that distinguish these forms of Bcr-Abl protein in patients with $\mathrm{Ph}$ '-positive leukemia at different stages of the disease. The transformation of cells expressing fusion protein Bcr-Abl, is associated with impaired regulation of tyrosine kinase Abl, namely its elevated levels in tumor cells, but there are the unidentified factors that lead to an exacerbation of the chronic form of the disease, its transition to the first stage of acceleration, and then to blast crisis. It has been shown that the Abl overexpression in cells does not lead to the tumor development, but rather results in inhibition of cell growth and apoptosis [10].

Therefore it was assumed that these specific features of $\mathrm{Ph}$ '-positive leukemias are caused by Bcr protein domains.

Analysis of dbl area of cDNA obtained from patients with CML, ALL. Based on the assumption that in some cases in the region of protein $\mathrm{p} 210 \mathrm{Bcr}-\mathrm{Abl}$, which is absent in protein $\mathrm{p} 190 \mathrm{Bcr}-\mathrm{Abl}$, might occur the changes that lead to the functional similarity of these chimeric proteins, we have analyzed the structure of the site in patients with $\mathrm{Ph}^{\prime}$-positive leukemia at different stages of disease. As a result, the deletions of varying length were detected in the region, corresponding to $\mathrm{Dbl}$ domain of Bcr protein, in several patients with acute occurrence of the disease $[11,12]$. In all cases, the deletions did not lead to disruption of reading frame. Similar changes were observed in the control group of healthy donors. Thus, we have shown that in some cases, in patients with CML and ALL with p210 Bcr-Abl at the acute stage of the disease there is a loss of sections of different length in DH region. So far, a number of submicroscopic deletions of varying length on chromosome $9^{\text {th }}$ ( $a b l$ gene), and on chromosome 22 ( $b c r$ gene) have been shown. In most cases, these changes reflected the progression of the disease and were an unfavorable prognostic factor.

The changes in the area of chimeric bcr gene that differ from the «classical» have been described by several authors - e6a2, e8a2, e13a2, e15a2 [13-16]. In most cases these changes were detected during disease acceleration. These transcripts have arisen as a result of noncanonical translocations that occurred in the areas other than the areas of $\mathrm{M}$-, $\mathrm{m}$-and $\mu$-Bcr of chimeric gene $b c r$ $a b l$. The changes described by us were different. The main difference was that these changes were not a result of an abnormal translocation type. The classic type of translocation was confirmed by RT-PCR at the stage of selecting samples for analysis.

Disease progression could not be a result of the effect of only one factor. However, it is likely that the lack of a domain or molecular changes in the region of exons 3-14 of chimeric gene bcr-abl (DH and PH domains) changes their functional activity, which leads to the formation of proteins acting differently. DH domains encode guanine exchange factors (GEFs) and work as a link between the surface cell receptors to cytokines, growth factors, G-protein receptors, adhesion, on one hand, and activation of Rho-like GTPases, on the other. Proteins p210 Bcr-Abl and p190 Bcr-Abl interact differently with GTPases RhoA, Rac1 and Cdc42 [17], which results in the implementation of their capacities, including influence on actin cytoskeleton, the NADPHoxidase during ROS formation, cell signaling, etc.

Study on actin cytoskeleton in leukocytes of patients with Ph'-positive leukemia. The actin-binding domains, present in the chimeric Bcr-Abl protein, interact with actin cytoskeleton and cellular localization [18]. To check the possible influence of these domains we have studied blood cells of patients with CML, leukemic cell cultures and leukocytes obtained from healthy donors. Comparative analysis of the actin cytoskeleton structures in polymorphonuclear leukocytes using FITC-labeled falloidin allowed us to distinguish three types of 
cell staining - cortical, diffuse and dot-like structures formation [19]. It has been shown that K562, U937 cells as well as cells of patients with $\mathrm{Ph}^{\prime}$-positive leukemia, have mostly cortical cytoskeleton distribution. In cells from healthy donors cortical cytoskeleton was almost non-expressed. In some cases, in addition to cortical F-actin large dot-like structures were detected in the cells obtained from patients with CML (blast crisis stage).

According to the literature data [18], changes in the organization of actin cytoskeleton may be associated with mutations in the $\mathrm{DH}$ region of $b c r-a b l$ gene and its dysfunction that affects Rho GTPases. It is well-known that DH domains are GEFs for Rho GTPases, causing actin cytoskeleton organization: the formation of phyllopoda, lamellopoda, stress fibers etc. To test this Dbl region of chimeric Bcr-Abl, the protein of patients with large punctates was used. The analysis revealed the presence of point mutations in this region [20]: transversions at position $2127(\mathrm{~T} / \mathrm{C})$ and at position $2449(\mathrm{C} / \mathrm{A})$. They lead to the substitution of phenylalanine for leucine at position 547 and threonine for lysine at position 654. The multiple alignment analysis of DH domains from eukaryotic proteins showed that the replacement of Rhe 547/Leu is neutral and does not affect the catalytic DH domain function because it does not change the class of amino acid residues and belongs to $\alpha$-helix $\mathrm{H} 2 \mathrm{~A}$ region. The latter is located on the inner side of $\alpha$ helical DH domain group that is not involved in the interactions with GDP, GTPases and neighboring domains. Instead, Thr654 mutation leads to substitution of a neutral amino acid residue for basic residue and belongs to the most conservative area of DH domain - CR3. Mutation Thr654/Lys was found within the CR3 sequence that forms a hydrophobic pocket for GTPase binding. This fact suggests that the appearance of charged amino acids in this region may have a decisive influence on the biological activity of Dbl-homologous domain.

Studying the GEF-activity of Bcr DH domain in vitro and in vivo. Currently more than 70 known proteins have DH domain in their structure. Most of them are GEF-factors for different GTPases [21]. Therefore we have tested the GEF activity in vitro by radioactive GDP release and the incorporation of $\gamma$-S35-GT recombinant proteins which contained DH and DHPH domains, and GTPases RhoA, Rac1, Cdc42. The experiments with transformation of 293T cells with DH and DHPH recombinant constructs and GTPases RhoA, RhoB, Rac1, Rac3,
Cdc42, Wrch1 have been also conducted. In both systems, no GEF activity on GTPases has been found [22].

Multiple alignment of amino acid sequences of DH family members showed that DH domain of Bcr has conserved amino acids that are responsible for forming the tertiary structure. It has also three conservative areas (CR1, CR2 and CR3) which may be involved in interactions with GTPases. Thus, the analysis of the primary sequence suggests that the DH domain of Bcr has all the structural elements that are present in the family of these domains, and therefore has the potential to function as a GEF-factor, perhaps, it might have specificity for other members of Rho family or Ras superfamily GTPases. In particular, these potential partners can be the following GTPases: Rap1, Rab5, Arf1. They have been selected because of their ability to interact with PLCE (presence of RA domain), the ratio of $\mathrm{PH}$ domain to membrane phospholipids (Rab5) and Golgi apparatus (Arf1).

Study on 190 and 210 Bcr-Abl proteins by fluorescent microscopy. As it was mentioned above, the difference between p190 and p210 Bcr-Abl is that p190 lacks the DH and PH part. It is known that there is a division within lipids by cellular compartments, so the presence of phosphatydylinositol-monophosphate-binding $\mathrm{PH}$ domain and $\mathrm{DH}$ domain in protein can most likely affect the localization of proteins and cytoskeletal organization.

Cos- 1 cells were transfected with the constructs expressing proteins $\mathrm{p} 190$ or $\mathrm{p} 210 \mathrm{Bcr}-\mathrm{Abl}$. The difference in their localization in cells has been shown in [23]. Both proteins were found in the cytoplasm, but p190 Bcr-Abl has an equable distribution in the cytoplasm of cell while protein $\mathrm{p} 210$ is characterized by mainly perinuclear distribution. So, Bcr part which is present in p210 and absent in p190 Bcr-Abl, has certain influence on the distribution of proteins. It has been supposed that $\mathrm{PH}$ domain takes part in Bcr-Abl localization. Cos-1 cells morphology did not change during transfection. Commonly, cells are round-shaped and have uniform distribution of actin filaments, cell membranes form neither lamellopoda nor phylopoda.

The influence of DH and PH domains was also tested in NIH3T3 cells which have been transfected with GFP vectors carrying these domains. The absence of obvious morphological changes was confirmed. This may mean that Rho family GTPases, involved in the reorganization of actin cytoskeleton, in this case were not 
activated, which would be expected if the $\mathrm{DH}$ domain of p210 Bcr-Abl protein had GEF-activity.

Determination of lipids interacting with $\mathrm{PH}$ domain of Bcr. PH domain has been described for more than 200 proteins, and it is involved in cell signaling, cell-cell interactions and cytoskeleton organization. It is known that in most proteins $\mathrm{PH}$ domain binds to phosphatydylinositols, so we decided to check if it is true for Bcr-Abl. Indeed, it was determined that Bcr-Abl binds to PI(3)P, $\mathrm{PI}(4) \mathrm{P}$ and PI(5)P phosphatydylinositol-monophosphates $[23,24]$. It has been shown that this interaction is highly affine [24]. The specificity of binding only phosphatydylinositol-monophosphate is not typical for $\mathrm{PH}$ family. Usually, PH domains bind with high affinity three phosphatydylinositol-three- and bisphosphates that are the products of PI3-kinase. The cellular lipids provide the distribution of signaling molecules and organization of compartment - specific signaling complexes [25].

That is, binding of Bcr or p210 Bcr-Abl to PI(3)P and PI(4)P can be a result of early endosomal or phagosomal or Golgi complex membrane localization of these proteins. The role of the binding of $\mathrm{PH}$ domain to PIP(5), which is localized predominantly in the nucleus, may be significant.

Investigation and analysis of the ability of $\mathrm{Bcr} P \mathrm{PH}$ domain to bind cellular proteins. It is known that $\mathrm{PH}$ domains of some proteins in addition to binding to lipids may be involved in protein-protein interactions [26]. To test this fact, the «pull-down» approach was used for the precipitation of proteins from K562 cells lysate and their subsequent analysis by proteomics methods. As a result, 26 proteins that interact with this domain were identified [23]. The next step was an analysis of interactions with proteins SMC1 (structure maintenance of chromosomes), $\beta$-tubulin, zizimin 1 and phospholipase CE (PLC $\varepsilon)$. To analyze the binding of $\mathrm{PH}$ domain, the DHPH construct, containing both $\mathrm{PH}$ and $\mathrm{DH}$ domains, was used. As a control, the DH only construct was used. Using a pull-down analysis, immunoblotting, and co-localization assay in HEK293T cells, the binding of PH domain to all proteins listed above was confirmed [23, 24]. The proteins identified belong to several functional groups, most proteins are involved in metabolic processes, cell proliferation, adhesion, signal transduction.

Using bioinformatic methods, the network of proteins and signaling pathways that interact with the $\mathrm{PH}$ domain has been constructed. It has three nodal centers:
ERK, NFKB and p38MAPK. Interaction with cortactin and protein FBP17, which are involved in the formation of early endosoms, may suggest that Bcr and Bcr$\mathrm{Abl}$ participate in this process. This assertion was supported by established interaction with Bcr $\mathrm{PH}$ domain of Bcr with PIP(3) - typical endosomal and phagosomal membrane lipids [23] and with ESCRT complex (proteins TSG-101 and Vps28) [27]. PLC $\varepsilon$ also participates in this process [23]. PLC $\varepsilon$ catalyzes the cleavage of phosphatydylinositol-4,5-bisphosphate to diacylglycerol and inositol-1,4,5-triphosphate $(\operatorname{Ins}(1,4,5) \mathrm{P} 3)$, which is a secondary messenger in many signaling pathways. PLCE has a bifunctional role: it is involved in lipid metabolism and also acts as GEF-factor for Ras GTPases. So, PLC $\varepsilon$ can regulate Ras (through its GEFdomain) and bind Ras-GTP, which potentially creates a complex mechanism of feedback regulation of a multicomponent system.

Localization of p190 and p210 Bcr-Abl in the cell relative to the Golgi apparatus. As it has been mentioned above we have shown that the PH domain has the ability to bind PI(4)P, which is the main component of lipid membranes of Golgi complex. It was therefore decided to investigate the co-localization of proteins p190 and p210 Bcr-Abl with Golgi apparatus. To do this, Cos-1 cells were transfected with the constructs expressing proteins $\mathrm{p} 190$ and p $210 \mathrm{Bcr}-\mathrm{Abl}$. For visualization of the Golgi apparatus the antibodies to the matrix protein GM130 were used.

It has been noticed that the protein p210 was colocalized with the Golgi apparatus, which typical shape was observed; in addition, p210 was also localized in cytoplasm. However, the highest concentration of protein was observed in the Golgi complex. p190 Bcr-Abl did not have such obvious location around the nucleus, it was evenly distributed throughout the cytoplasm of cells [23]. The specificity of the interaction was tested by adding wortmannin which led to delocalization of p210 Bcr-Abl in the area where it has been detected before treatment. The results of co-transfection with costructs bearing shRNA specific to PI4K and PTEN also showed the effect of reduced binding of p210 to Golgi complex.

Thus, it was shown that the presence of PH domain affects the subcellular localization of this protein, causes the interaction with various proteins and organelles of the cell. First, it is a participation in the endosomes 
formation. The proteins that interact with the $\mathrm{PH}-$ domain of Bcr (cortactin, FBP 17, PLC $\varepsilon, \beta$-tubulin) take part in this process. Thus, the interaction of $\mathrm{p} 210 \mathrm{Bcr}-$ Abl protein with TSG10, a component of the complex ESCRT1, might be explained [27]. Despite the lack of $\mathrm{C} 2$ domain of Bcr protein, which is responsible for $\mathrm{Bcr}$ binding to the protein TSG101, the interaction is still observed in the cells expressing p210 Bcr-Abl. This fact is well explained by the data established by binding PH domain to PI(3)P, a dominant early endosomal lipid. The absence of this domain in protein p190 Bcr$\mathrm{Abl}$ alters endosomal sorting and direction of growth factors receptors transport and differentiation. Differentiation of hematopoietic cells depends not only on the growth factors receptors, but also on their internalization and degradation in time. Thus, aggravation of endosomal transport and accumulation of differentiation factors, which cannot be degraded, on the cell surface may affect the differentiation of hematopoietic cells. The presence of $\mathrm{PH}$ domain determines the high affinity of binding Bcr to PI(3)P on early endosomes and phagosomes. Lack of GAP domain at $\mathrm{COOH}$ end of $\mathrm{Bcr}$ part leads to deregulation of Rac GTPase, resulting in the constitutive activity of Rac in hematopoietic cells, increased formation of reactive oxygen species and emerging of «oxidative burst» [28].

Improving the detection of Philadelphia chromosome in patients with CML and ALL and monitoring patients during treatment with Abl kinase inhibitors. One of the main problems in the treatment of CML is emerging of new mutations that make the drugs, including Abl kinase inhibitors, unable to work. More than 50 mutations within the kinase domain of Bcr-Abl protein, most of which lead to lost or reduced efficiency of Imatinib, one of the main drugs for CML treatment, have been described. Therefore, detection of these mutations is important for selecting the treatment strategy. Since most of these mutations arise in region 200-400AK of Abl, and mutations M244V, G250E, Y253F/H, E255K/V, T315I, M351T, F359V are more than $85 \%$ of the mutational changes, the primers for nested PCR of this site were designed. The most common mutation is T315I, which leads to the replacement of threonine by isoleucine and causes a loss of effectiveness of the imatinib [29].

Thus, in this study, it has been shown for the first time that Bcr part of the Bcr-Abl fusion protein plays a significant role in the mechanisms of tumor develop- ment during CML progression. It determines the specificity of different oncoproteins (p190, p210, p230), due to their different localization in the cell and participation in different signaling cascades. This fact, in addition to the traditional use of Abl-kinase inhibitors, increases the possibility of targeted therapy of $\mathrm{Ph}^{-}$-positive leukemia. Given the high genetic instability in patients with myeloproliferative disorders, the test systems for a) detection and differential diagnosis of $\mathrm{Ph}$ '-positive leukemias by RT-PCR, and b) monitoring changes in ATP-binding region of Abl protein were developed, allowing clinicians to adjust therapy when mutations in this region occure during tyrosine kinase inhibitor treatment. Under the current classification of the World Health Organization (4.5) molecular diagnostics is an obligatory component of modern diagnostics of leukemias. In collaboration with the colleagues from the Immunocytochemistry department of Kavetsky Institute of Experimental Pathology, Oncology and Radiobiology of NAS of Ukraine) we have developed a protocol for detection of the most characteristic MPN mutations, namely Jak2, mpl, tet2, asxl1 [30], and mutations in acute leukemia mll/af4 (t $(4,11)$ (q21; q23); mll/af9 (t $(9 ; 11)(\mathrm{p} 22 ; \mathrm{q} 23)$; cbfb/myh11 (inv16) [31]. The effectiveness of this protocol was tested on a large number of patients. This greatly improved diagnostic and therapeutic protocols for leukemias of various origins in Ukraine.

Г. Д. Телегеєв, М. В. Дибков, А. М. Дубровська, Д. О. Мірошниченко, А. П. Тютюнникова, С. С. Малюта

Розвиток молекулярної онкогематології в Україні

Резюме

Обов'язковим і характерним елементом злоякісної трансформаиії є порушення генетичного компонента клітини. Для більшості неоплазій системи крові генетичні порушення є відомими, що дозволяє використовувати їх для діагностики і відповідної терапї. Наведено авторські дані стосовно ролі доменів білка Bcr-Abl (головного етіологічного фактора в патогенезі лейкемій з філадельфійською хромосомою) та представлено апробовані методи діагностики мієлопроліферативних захворювань і гострих лейкемій.

Ключові слова: мієлопроліферативні неоплазми, Bcr-Abl, Jak2, молекулярний патогенез, діагностика.

Г. Д. Телегеев, М. В. Дыбков, А. Н. Дубровская, Д. А. Мирошниченко, А. П. Тютюнникова, С. С. Малюта

Развитие молекулярной онкогематологии в Украине

Резюме

Обязательным и характерным элементом злокачественной трансформации являются нарушения генетического компонен- 
та клетки. Для большинства неоплазий системы крови известны генетические нарушения, что позволяет использовать их для диагностики и проведения соответствующей терапии. Приведены авторские даннье о роли доменов белка $\mathrm{Bcr}$ - $\mathrm{Abl}$ (главного этиологического фактора в патогенезе лейкемий с филадельфийской хромосомой) и представлены апробированные методы диагностики миелопролиферативных заболеваний и острых лейкемий.

Ключевые слова: миелопролиферативные неоплазмы, $\mathrm{Bcr}-\mathrm{Abl}$, Jak2, молекулярный патогенез, диагностика.

\section{REFERENCES}

1. Fedorenko Z. P., Goulak L. O., Gorokh Y. L., Ryzhov A.Yu., Soumkina O. V., Koutsenko L. B. Cancer in Ukraine, 2011-2012. Incidence, mortality, activities of oncological service // Bull. Nat. Cancer Registry of Ukraine / Ed. I. B. Shchepotin.-Kyiv, 2013.-73 p.

2. Tefferi A., Vainchenker $W$. Myeloproliferative neoplasms: molecular pathophysiology, essential clinical understanding and treatment stra- tegies // J. Clin. Oncol.-2011.-29, N 5.-P. 573-582.

3. Glusman D. F., Sklyarenko L. M., Nadgornaya V. A. Diagnostic oncohematology.-Kyiv: DIA, 2011.-254 p.

4. Tefferi A., Vardiman J. W. Classification and diagnosis of myeloproliferative neoplasms. The 2008 World Health Organization criteria and point-of-care diagnostic algorithms // Leukemia.2008.-22, N 1.-P. 14-22.

5. Swerdlow S. H., Campo E., Harris et al. WHO Classification of Tu- mours of Haematopoietic and Lymphoid Tissues / Fourth Edition.- Lyon: IARC Press, 2008.-439 p.

6. Telegeev G. D., Dybkov M. V., Karpenko O. I., Cherepenko H. I. Molecular basis of $\mathrm{Ph}^{\prime}-$ leukemia and finding the way to treat them // Biopolym. Cell.-1994.-10, N 5.-P. 78-92.

7. Telegeev G. D., Dybkov M. V., Bozhko M. V., Tretiak N. M., Maliuta S. S. Molecular-biology approaches to detection of Philadelphia chromosome in patients with leukemia // Biopolym. Cell.-1996.-12, N. 6.-P. 63-68.

8. Telegeev G. D., Dybkov M. V., Bojko M. V., Tretyak N. M., Maliuta $S$. S. Molecular biological diagnostics of blood neoplastic diseases // Tsitol Genet.-1998.-32, N 1.-P. 71-78.

9. Telegeev G. D., Dybkov M. V., Bojko M. V., Demidenko D. V., Maliuta S. S., Tretyak N. M., Bondar M. V. Monitoring of chronic myeloid leukemia by molecular-biological methods [guidelines].- Kyiv: The National Centre for Scientific Health Information Health of Ukraine publ., 1997.-16 p.

10. Sawyers C. L., McLaughlin J., Goga A., Havlik M., Witte O. The nuclear tyrosine kinase c-Abl negatively regulates cell growth // Cell.-1994.-77, N 1.-P. 121-131.

11. Telegeev G. D., Dybkov M. V., Dubrovska A. N., Maliuta S. S. Deletion of the fifth exon of $b c r / a b l$ gene by acute lymphoblastic leukosis with Ph' chromosome // Biopolym. Cell.-2001.-17, N 4.-P. 298-301.

12. Dybkov M. V., Telegeev G. D., Dubrovskaya A. N., Maliuta S. S. Deletion in dbl domain of $b c r / a b l$ gene in leukemia patients with Ph' chromosome // Exp. Oncol.-2002.-24, N 2.-P. 153-154.

13. Popovici C., Cailleres S., David M., Lafage-Pochitaloff M., Sainty D., Mozziconacci M. J. E6a2 BCR-ABL fusion with BCR exon 5-deleted transcript in a Philadelphia positive CML res- ponsive to Imatinib // Leuk. Lymphoma.-2005.-46, N 9.-P. 1375-1377.

14. Colla S., Sammarelli G., Voltolini S., Crugnola M., Sebastio P., Giuliani N. E6a2 BCR-ABL transcript in chronic myeloid leukemia: is it associated with aggressive disease? // Haematologica.2004.-89, N 5.-P. 611-613.

15. How G. F., Lim L. C., Kulkarni S., Tan L. T., Tan P., Cross N. C. Two patients with novel BCR/ABL fusion transcripts (e8/a2 and e13/a2) resulting from translocation breakpoints within BCR exons // Br. J. Haematol.-1999.-105, N 2.-P. 434-436.

16. Moreno Mdel P., Cortinas M. N., Bonomi R., Cardeza A., Uriarte Mdel R. A novel BCR-ABL fusion transcript (e15a2) in 2 patients with atypical chronic myeloproliferative syndrome // Blood.-2001.-97, N 11.-P. 3668-3669.

17. Harnois T., Constantin B., Rioux A., Grenioux E., Kitzis A., Bourmeyster $N$. Differential interaction and activation of Rho family GTPases by p210 bcr-abl and p190 bcr-abl // Oncogene.2003.-22, N 41.-P. 6445-6454.

18. McWhirter J. R., Wang J. Y. Effect of Bcr sequences on the cellular function of the Bcr-Abl oncoprotein // Oncogene.-1997.15, N 14.-P. 1625-1634.

19. Dubrovskaya A. N., Telegeev G. D., Dybkov M. V., Voloshanenko O. S., Shved V. V., Maliuta S. S. Mutation analysis and bacterial expression of the chimerical oncoprotein Bcr/Abl Dbl-homology domain // Biopolym. Cell.-2002.-18, N 2.-P. 96-101.

20. Telegeev G. D., Dubrovska A. N., Dybkov M. V., Maliuta S. S. Influence of $\mathrm{Bcr} / \mathrm{Abl}$ fusion proteins on the course of $\mathrm{Ph}$ leukemias // Acta Biochim. Polon.-2004.-51, N 3.-P. 845-849.

21. Oleksy A., Opalinski L., Derewenda U., Derewenda Z. S., Otlewski $J$. The molecular basis of RhoA specificity in the guanine nucleotide exchange factor PDZ-RhoGEF // J. Biol. Chem.2006.-281, N 43.-P. 32891-32897.

22. Miroshnychenko D. O, Teleheiev H. D., Maliuta S. S. Analysis of GEF activity of Bcr protein DH domain // Ukr. Biokhim. Zh.2007.-79, N 5.-P. 116-121.

23. Miroshnychenko D., Dubrovska A, Maliuta S., Telegeev G., Aspenstrom $P$. Novel role of pleckstrin homology domain of the Bcr-Abl protein: analysis of protein-protein and protein-lipid interactions // Exp. Cell Res.-2010.-316, N 4 P. 530-542.

24. Miroshnychenko D. O., Dubrovska A. M., Telegeev G. D., Maliuta $S$. S. Protein-lipid and protein-protein interactions of Bcr $\mathrm{PH}$ domain // Biopolym. Cell.-2007.-23, N 5.-P. 405-409.

25. Czech M. P. Dynamics of phosphoinositides in membrane retrieval and insertion // Annu. Rev. Physiol.-2003.-65.-P. 791-815.

26. Lemmon M. A., Ferguson K. M. Molecular determinants in pleckstrin homology domains that allow specific recognition of phosphoinositides // Biochem. Soc. Trans.-2001.-29, Pt 4.- P. 377-384.

27. Olabisi O. O., Mahon G. M., Kostenko E. V., Liu Z., Ozer H. L., Whitehead I. P. Bcr interacts with components of the endosomal sorting complex required for transport-I and is required for epidermal growth factor receptor turnover // Cancer Res.-2006.66, N 12.-P. 6250-6257.

28. Reddy M. M., Fernandes M. S., Salgia R., Levine R. L., Griffin J. $D$., Sattler M. NADPH oxidases regulate cell growth and migration in myeloid cells transformed by oncogenic tyrosine kinases // Leukemia.-2011.-25, N 2.-P. 281-289.

29. Cortes J., Jabbour E., Kantarjian H. et al. Dynamics of BCRABL kinase domain mutations in chronic myeloid leukemia after sequential treatment with multiple tyrosine kinase inhibitors // Blood.-2007.-110, N 12.-P. 4005-4011.

30. Dybkov M. V., Gartovska I. R., Telegeev G. D., Maliuta S. S. Development of test system for detection of $\mathrm{V} 617 \mathrm{~F}$ mutation of Jak2 gene in patients with chronic myeloproliferative disorders // Science and Innovation.-2009.-5, N 6.-P. 59-63.

31. Glusman D. F., Sklyarenko L. M., Nadgornaya V. A., Zavelevich M. P., Poludnenko L. Yu., Ivanovskaya T. S., Ukrainskaya N. I., Telegeev G. D., Dybkov M. V., Polischuk L. A. Development of complex of immunocytochemical and molecular genetic technologies of acute leukemias diagnostics and their implementation into clinical practice // Science and Innovation.-2013.-9, N 1.-P. 44-54.

Received 20.05.13 